THE IMFOORTANCE OF PHASE IN BIOLOQICAL SIGNALS

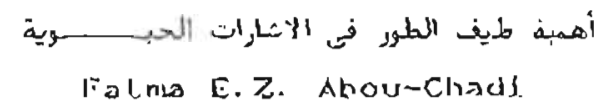

Facully of Ergjneering - Mansouxa Universily

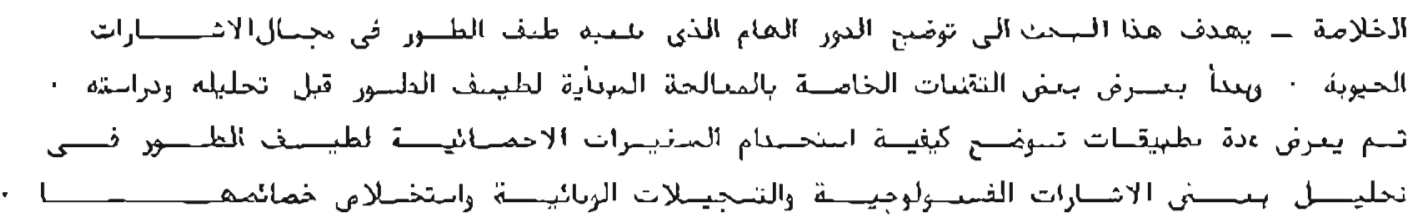

ABSTRACT- In Lhis paper, the importance of plase In the context of biological signajs is hiqhlightened. Techniques for manipulating the phase spectral values prlor to its use are lllustrated and several approaches to exploit the role of phase statistics in biological siçnal analysis and feature extraction are discussed.

\title{
X. TNTRODUCTION
}

In fourier representalion of signals, spectral magnilude and phase tend to play diffexent roles and in sone sltuatlons, many of the important features or a sigual are preserved if only. the phase is retalned. A corresponding statement can not in general be made for the spectrol magnitude (Oppenheim and Lim, 1901 ). This observation about phase has been made in a number ol different conlexts and applications including one-dimengional, two-dimengional and thxee-dinensional signals. In sueech, cor instance, it has been shown lhat the intelijgluilily of a sentence is retained if the phose of the fourier lianstorm of a lona segment is combined with unlty nagnitude (Rablner and scha[er, J.978). It has been reported by llayes and oppenhien, (2980) that many of the Lealures of an uriginal image are clearly identifiable In the phase-only image reconstructed but not 1 in the magnilude-ondy image. This suggests very strongly the lact that In many contexts tise phase cuntains much of the essentlal "intorination " in a signal.

The present paper brinys emphasis to the role that phase plays in the context of blological signals: physiologlcal and epldemiologlcal records. Section / l Jemonstrates some cechniques Eor manipulating the raw phase spectral values prlor to lis use. The importance of phase in pattern detection his a number of inportant bniplications with reqard to applicaljons. In section III, we review some lechniques that have been developed and utilized and be conslder some specilic applications. 
II. PHASE SPECTRAL MANIPUIAATYONS

The complex fourier specteum $X(E)$ of a real sjgnal $x(t)$ is befined as

$$
X(E)=\int_{-\infty}^{\infty} x(L) \exp (-j 2 n t E) \text { d }
$$

where $x(t)$ can be given by

$$
x(L)=\frac{1}{2 \pi} \int_{-\infty}^{\infty} x(E) \exp (j 2 r L E) d t
$$

In the general case, we dead with. waveforms of finite duration, hence

$$
\begin{aligned}
x(t) & =x(t) & & t_{1} \leqslant t \leqslant t_{2} \\
& =0 & & \text { elsewhere }
\end{aligned}
$$

In this case the integratlor in Eq. (1) is limited to the closed interval $\left[t_{1}, t_{2}\right)$.

The frequency component (harmonic) $X(E)$ is a complex guantity with real and imaginary parts denoled by R(E) and I(E), cespectlvely. $X(E)$ has an amplitude $\Lambda(E)$ and phase $\phi(E)$ defined by

$$
\begin{aligned}
& \Delta(E)=\sqrt{R^{3}(E)+I^{2}(E)} \\
& \phi(E)=\operatorname{arctg}\left\{\frac{I(E)}{R(E)}\right\}
\end{aligned}
$$

In practice $x(t)$ is sampled at an approurial:e sampling Erequency and the distrele Fourier transform is calculated with the lie $1 \mathrm{p}$ of: the fast fouriex reansform (FFT) algoritim.

The phase spectrun calculated by E. (5) can be considered as contributed by two additive factors: the phase efect due spechfically to the shape of the waveform, and those due to the Eact that the signal is generaliy olsplaced away. Erom its most nearly symmetrlcal position with respect to zero time in the record. In Erequency domaln terms, the signal is treated as if it repeats on a time-base equal to the chosen record length; the phase spectrum after "spinning" on its time base to its most symmetrlcal position is treated as that contributed to lie waveform alone. But since in general the maln pattern features of a signal exhiblt an arbitrary displacement from their temporaliy most-symmetrlcal position, Lhls adds a pliase shiet proportional to the relevant time delay and to harmonic number. The resulting phase angle may then be subject to complication by "wrapraround" into the principle angle range.

\section{1 The Wrap-Around Errect}

Although the phase components calculated from Eq. (5) can have values in the range $(-\infty, \infty)$, the values of 
mapped in the reglon $(-\pi, n)$. Thls is diue to the periadic character of the arctg function. In fect, o(c) shiuld therefore be wrltien as.

$$
\phi(E)=\operatorname{arctg}\left[\frac{I(E)}{k(E)}\right]+2 k n,: k_{n}=\ldots,-2,-1,0,1,2, \ldots
$$

Thls is known as the wrap-around effect.

The elfect of wrap-around can be ellminatcu by an unfolding (unwrapping) procedure. This can be made by adding or subtracting multiples of $2 n$ to the phase values at approprlate frequencles in order to make all the differences of two consecutive phase spectral values less than $\pi$. The removal of the lolus in the phase spectrum ceveals any trend which may be present. This represents the displacement of the maln signal Eeaturas Exom Lieir temporally most-symmetrical postion. The gradicut of the trend ls proportional to the relevant time delay and to the harmonlc number. It may be positive or negatlbve depending on whether the sigial is acivanced forward or delayed after the onset time. Therefore, the unwrapglng procedure must be follawed by a linear regression and a trend removal. The whole process is known as "Requession Splnning" (Sutton, 1900)

IT. 2 Remoring The Trend

$\lambda$ least-square error line is fltted to the phase spectrum and the calculated trend is zemoved - the phase spectrum will then have 1 o increments greater than in radlans, and no ovecall crend. Úsing thls method, specially on complex slqnals, it is often found that the unfolded and trend-removed phase spectrum exhibits phase Increments greater than tr radlans, and the reconstructed slgnal is evidently not centeced. The folds produced by the removal of best-fie line occur at points where the signal power Is low. At liese polint, sudjen 'jumps' ocrur in the phase spectrum isayers, 1971). Regression spinning surmounis this problem by removing these secondary folds by unfolding the phase spectrum once more, and then removing any Euclier trend that emerges. The resultant phase spectrum can now be consldered as that contributed by the the signal pattern features alone ond can be ut llzed for diffrcent purposed. Fig.l shows a typical example of uncolded spun phase spectrum of an arbitrary signal.

III. APPLICATIONS

IIT. 1 Pallarn Delectlon

The exlstence of ary systematic pattern, underiying an ensemule of records is problemallcal. Some basis eor comparison Is needed: for instance, by lesting the records in question agalnst otherwise simllar records thot certalniy do nut contain the pattern. The most objective approach is one chat depends upon the propierties of the phase spectrum of the signal.

An ensemble of random signals will exhiblt uniformly random pliase spectra for each harmonic ond, subject to statistical sampling elfetis, Lhis can be uscu for lesting purposes, because 
the presence in all signals of a common pattern imposes a measure of phase aggregation in relevant hazimonlcs. Horeover, if a visluly discermable pattern is present Jn s record, then the incremental phase spectrum (between successive harmonlcs) is magnitude-limited, and this also may be usableisayers et al., 19741 .

IIJ.1.2. Using Phaso Aggregation

If lhe same response pattern was present in each of an ensemble of records, some aggregation should occur in lhe distribution of the phase-spectral values for individual celevant harmonics as depicted in Fig.?. In the absence of any conslatert patlerns, a unfform distribution of the engemble of phases would be expected tor each harmonic (3ayers et al., 1971). This method has proved to be of some value in different physloloyical records were it is required to detect the response "of a stimulus. For example, sayers et al., (1979) and Beagley et al. (1979) have applied this technigue to the delectlon of auditney evoked potentlals ln the electroencephalography (EEG). Pattern aspects of Individual post-stimulus responses were exanined by the ensemble distribution of phase values of Fourier spectral components employed to characterlze signal pattern. The indivldual harmonic phase values were distclbuted approximately uniform Ear ungtimulaked EEG, but were demonstrated to be increasingly aggregated cor increasingly suprathresliolo stimull. it Is approved that a lully objective audiometic technique can be based on this method and that the presence or absence of an auditory-evoked potential ( $₫ E \mathrm{E}$ ) can be decided withoul the intervention of the tester, thereby removing the tester bias.

Ifi.l.b Using Ensembia Slardai=d Deviation of Phase

One of the most efticient techniques based on statistlcal pattern analysis has been developed for measuring hearing theeshold (Ross, $\Lambda$. J. 1978). The technique uses the phase Etandard deviation of harmonic components as a measure of consistent pattern content occurcing throughoul an ensemble oE records. It involves a conventional non-parametric statistical test to declde whether the. distcibution of phase values for inuividual harmonic components of a riumber of post-atimulus EEG records is uniform. If the whase ellsemble of a harmanlc component exhiblts aggregalion, the ensemble standard deviation value should be signicicantly small compared to lhat of a uniformly distributed ensemble. On the other hand, in the case of no constraint, a large ensemble standard deviation value (about $\pi / 3$ ) ls expected (Sectlon I I I. J).

\section{IIX.2. Decomposhtion and Disaggregation}

Linear decomposition of a signal into ils components can sometimes be done by Ilnear Eiliering. More often, it is necessary to identify empirically any common or cecurrent Eeatures and then to 130 atie tiem, using knowledge about the ldentifled fealure and about its occurrence locations. Disaggregation 13 a term from statistical epldemiology; il means 
ine operation of splitting a record into known contributury parts, for instance according lo the geographlcal reglons from which data ls obtained, or by separating the contributions by tlme (seasonally, say) for separate study. The approach call be illumbating by examindng specific slgnals in which the inspection of the spectrel phase values is very useful to this end.

$\Lambda$ numbex of authors have used the phase aggregation concept in order lo ldentlfy the presence of a common pattern or a standard form in an ensemble of records; epldemiological and pliyslological (sayers et al., 1902 and sayers et al, 1983). Thls may help in establising a reference representatlve pattern for the common beliavior of lise records.

Fig. 3 shows an ensemble of postmeonatal dally death records due to gastrointestinal causes In Dakahlia governorale over yeara 1981-1987. The recoros exhibit long-term (seasonal) variations. Moreover, Jregular recurrent short-duration Increases in the number of deaths which might be 'nolse' or might be due to posslble blologlcal origin can be observed. Therefore, each record can be regarded as composed of a long-lerm seasonal component added to high Erequency lrrequiar component. $\lambda$ convenient approach is to separate these components using Wltering operations. Accordingly, some basls tor chaosing the extent of filtering should bo sought. It has been reported by Abou-chadl et al., (1990) that the record phase spectra have shown a clear phasc aggregation in harmonlc components (13, to $\left.H_{6}\right)$

(FIg.1). This indicated the existence of a common pattern in the ensemble of records. This common pattern refiects the seasonal behavlour and was isolated from each record Eor further Investigation (Fig.5).

'The same procedure has been also applied to 24 -hour adust heart-rate and ambulatory intra-artertal blood-pressure records (5ayers et al.,1982 and 1.983). It has been regorted that records do exhlbli two vell known features: very large varlabllity superimposeu on a crudedy circaulan pattern. The clrcadian pattern reflects the fact that the heart-rale and mean blood pressure seems to drop at night during rest, rislng again in the morning; the patterns of $r$ ise and fall are rather varlable belng Ilnked to the sleepling cycle of the subject. The existence of the common circadian pattern is reflected on the phase values of the orlglnal records in the form of aggregation in the relevant harinonles. This leads, in turn, to identifying the contributing components to the clrcajian pattern and thereby its lsolation.

However, In the analysis of 21 -hour heart-rate in neonates (Abou-Chad, 1986), the olstcibution of the phase spectral values for the relevant harmonles have been found to be bimodal (Flg.6). Thls has been considexed as an indication that the common long-term pattern in the neonatal heart-rate signal l les in more than one standard form and that each mode is certainly related to some maln teatures. These results have led to classifylng the long-term betravior into three distinct forms. This has been achleved by comparing lhe phase values of the different records and relate them to the nearest modal values. IHere the term 
clrcadian ls not valid due to the difeerent sleening and waking times ln meonatesl.

III. 3 Velddalion of The Occurrence of a Recurrent Patlern

If a recurrent pattern can be observed as the major component in a signal, it may be poselble lo egloblish whether it is a pattern due to some underdying mechanisn or it is omiy Eluctuation that can be interpreted as an unwanted "noise" or "osclilation". An example l's the cesldual slgnal that rewmalns after removing the long-term pattern from biological varlables. Flg.7 shows the cesldual slgnal cor postrienralial juatil records and that of the neonatal heart-rate records. The signal shows ghort-ierm recurcences of $r$ ise and $\mathrm{fall}$, and therefore, it is Important to determine the entity of these transient fecurrences. The plase spectral analysis has been efficlently apolied to examlne the validation of the occurrence of lhese transient recurxences as an expliclt entity. Thls has been achleved by reconstructing the residual signal using the original amplitude spectrum of the signal and arandorlzed phase spectrum derlved from uniformly phase values $(-\pi,+\pi)$. the reconstructed signal is shown In Flg. a obtained by the present author ill a previous vork. Comparing the orlginal and resyntiesed signals, we gee clearly that the slgnal main features have been altered. This has been proved by comparling the statistical porameters for the translent occurcences (e.g. shape of the average transicnt pattern, amplitude and inter-event Incervals).

III. 1. Extimating the Dandwalh of a Signal

In establishing the specilicalion for the instrumental measurement of say, electrocardlograplic (ECG) waveforms, It is necessary to dekermine the slgnal bandwldth. Thls cannot be based on observations of the amplilude or power spectrum without a prlorl estimate of the regulred answer; it is not warcanted to InEer the result merely by specifying the hlghest erequency exhlolting glgnificant power. However, an aporoach can be made using tise statistical varlabllity of the wavelorm phase speclra. In order to select Indlvidual waveforms of ECG from a continuous record, the starting polnt of each wave must be laentifled. This is invariably subject to uncertainty resulting in the adaltion of a randor latency to each wavetorm. This effect adds a plase shift, proportional to hacmonic number ana to latency value, into the phase spectrum of the wavefurm. In the complete ensemble, this effect contrlbutes an ensemble standard deviation of plase whicl is proportional to frequency, at least for spectral components that are coherently linked to the cardiac beal. For spertial components that are not time-ilnked in this way, and 50 not part of the CCG slgnal, the eftect of fluctuating latency amongst the different beats in the ensentif is to contr lbute randam phase shifts that result in total phase values that are unfformly distributed across the avaliable range of phases. The ensemble standard deviation of a randon variable which is uniformly distrjuuted over the range from - I80 to t180 is calculable to be 103.9 (Eendat and Jansen, 2971 ). 
Therefore, Lhe curve of ensemble standaco deviation of phase as a Eunction al trequency r lses llneacly al low frequencieg. It [luctuates around a constant value (which approxlinates $101^{0}$ for larae ensemble slzes) for spectral components that are not lime-locked lo the ECG beat (Fig-9). It is easy to set a sultable upper limlt lo the siymad-linked spectrum for such an ensemble. and thus to ldentify lie effective bandwidth speclelcation for the slgnal (Rompelman et al., 1982 and Nbou-Chadl et al., 1990).

\section{TV. CONCLUSION}

Some applications of the use of phase spectidal values in the context of blological signals have been presented. They ara lilustralive of ways in which bhe lmporlance of phage can be explolled. They serve to demonstrate and assert that in a number of contexts the fourier liransform pliase contains more "Inuortant" Information than the Eourlec traistorm magnitude. Similat conclusions have been dxaun in speecl and image sjgnals, optical holography and $x-r a y$ crystallography (oppenhiem and $6(m, 1981)$.

\section{RETERENCES}

1- Abou-Chad, F.E.Z. $(1986)$. The signal structure of Infant long-term epldemlologlcal and plystulogical records. Ph.D. Thesls, Impertal College, Unlvergity of fondon.

2. Nbou-Chadl, E.E.7., Nodel-Fattah, A.I., and El-Gayar, M. (1990). "Pattexn analysis of gastrointestjnal postneonatal dally dealh counts in Daxalilla (1981-1987)," Proc. of the $25^{\text {thannual }}$ contexence on statistics, comp. and op. cesearch, vol.25, D: . 3: $1-15$.

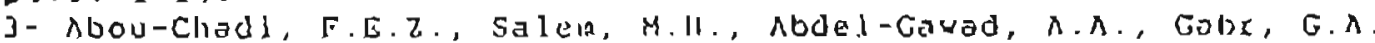
1990). "Án dmproved ECG data ceductiun algorithm using Fourjer descelptozs", Mansoura Enh. J.. vol-15. No.7:39-50.

1-Beagley, H.A., Sayers, B.MCA, and Ross, A.J. (1979), "Fuldy objective ERA by pliase spectral analysis, "neta otolaryngol, 87 : $270-278$.

5- Bendat, J.S. and Jansen, X.C. (1971). Random data: analysls, measurements, procedures. 3. Hlley.

6- lsayes, M.H. and Oppenhein, K.U.(1.900), "Signal reconstruction Erom phase or maquitude," IEEE Trans. Acoustics, speech and slgral Processing, vol. Assp-28, No.6: 672-680.

7- Oppenhelm, $\lambda . v$. and $[1 \mathrm{~m}, \mathrm{~J}, \mathrm{~S}$. (1981), "The Importance of phase in signals," Proc. IEEr, vol.69, No.5: 5?9-551.

B- Rablnex, L.R. and Schafer, R.W. (1978). Digilad processling of speech slgnals. Engelwood Cliffs, NJ. Prinllec llall.

9-Rompelman, D. and Janben, R.J. (L9B?). "Use of pliase spectral information in assessmelt of Erequency contents of ECG waveforms, "Proc. IEE, vol.129, pt.A, No.9: 679-603.

10- Ross, A.J.(1978). Objective detection by slgnal analysis of the auditory evoked EEC polentlal. Ph.D. Thesis, Imperlal Colleqe, Unlversity of solldon.

11- Sayers, a.McA. and Beagley, II. $\Lambda$. (1971). "Objectlve evaluation of auditory evoked EEG responses," ivaluze, 251: $600-609$

12-Sayers, 8.Hch., Beagley, H. A., ond Riha, J. (1979), "Pattern analysis of Audltory-evoked EEG potentlals," Audlometry 18: 1-16. 13-Sayexg, B.MCA., Cicchiella, L.R., Raftery, E.B., Mann, S. and Green. H. (1992), "The assessment of cont lnuous ambulatory blood 
pressure records." Med. Infurin., vol.7, No.7: 93-108.

11-Sayers. B.Mch. and Cicchleilo, L.R. (1983). nmbulatory blood presisure Blgnol featuxes: Identilication, Measurement and Implications. Ambulatory Monltozlng-cardlovascular system and alled applications. Edilox: Carlo Machesl. Martinus Nifhofe publishers. Chapter 3: 255-262.

15- Sutton, P.R. (1980). Regression spinning and the standardisation of phase spectra. Rh. D. thesls, Imperlal College, Universlty of Lonoon. 
Mansoura Englneerlnq Journal (MEJ), vol.16, No.2.Dec. 1991

$E-27$

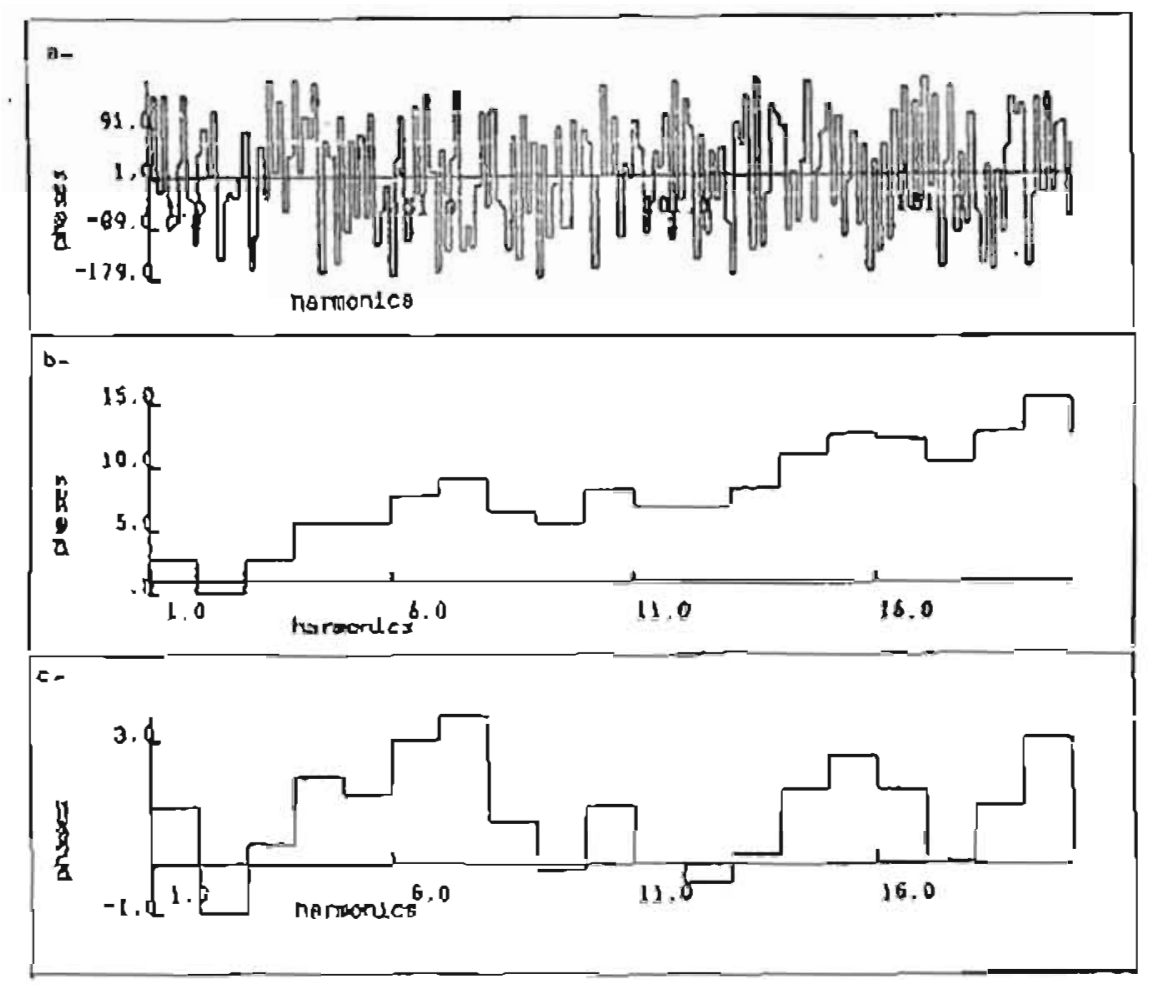

Flg.l in example of phase spectrum of an arbltrary slynal a- Pliase values calculated Erom the arctg function b- Unfolued phase values

c- Phaze values epun to the signal most-synnetrical position.

$3-$

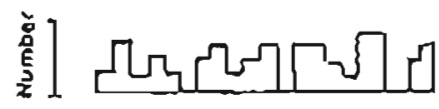

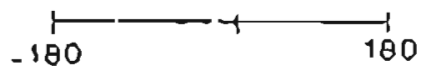

b..
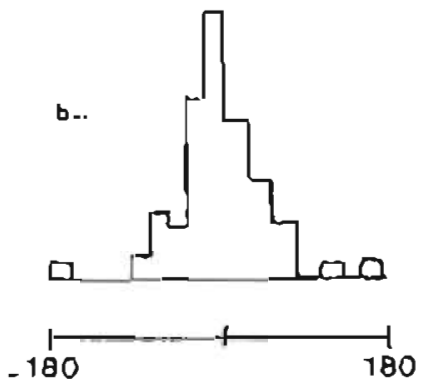

Fig.2 Typlcal behavioux of phase distrlbutlons a- Uniform distrdbution b- Phase distribution In carie of aggxegatiun 


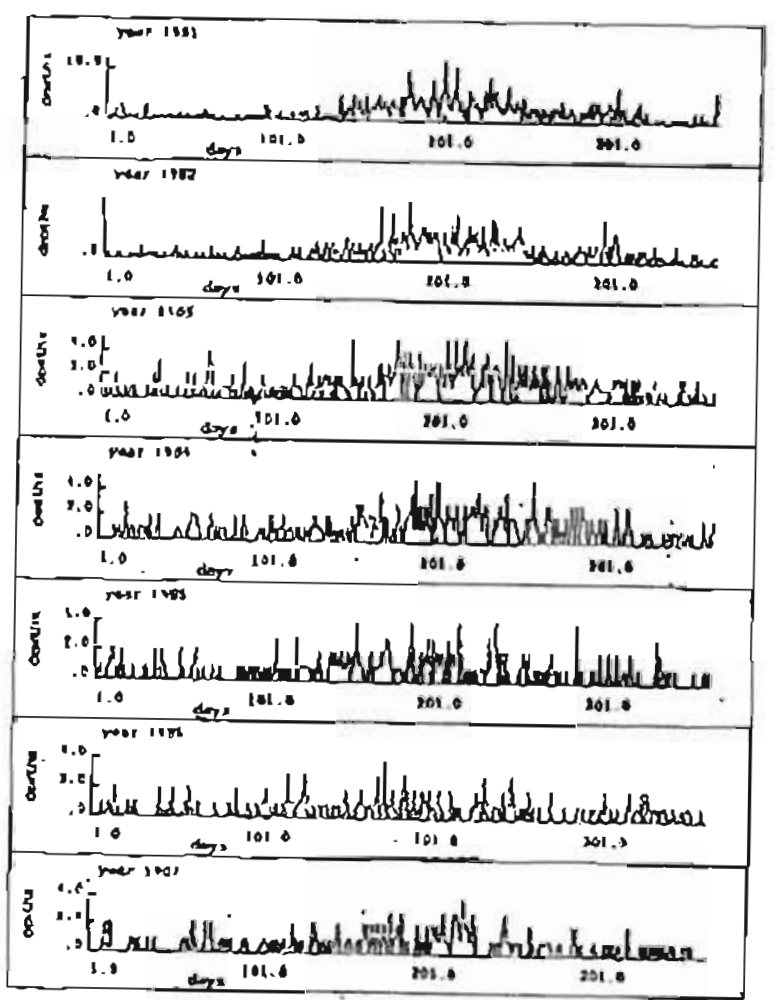

Fig. 3 Ensemble of 7 records of postneonatal daily deaths

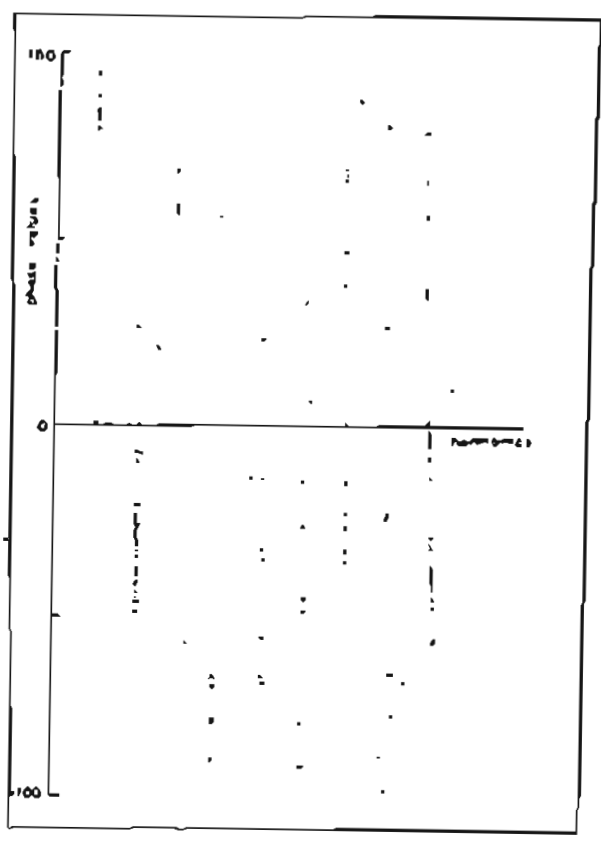

Fig. 4 phase values of harmonies $\left(H_{1}-I_{10}\right)$ of records in Pig. 3 


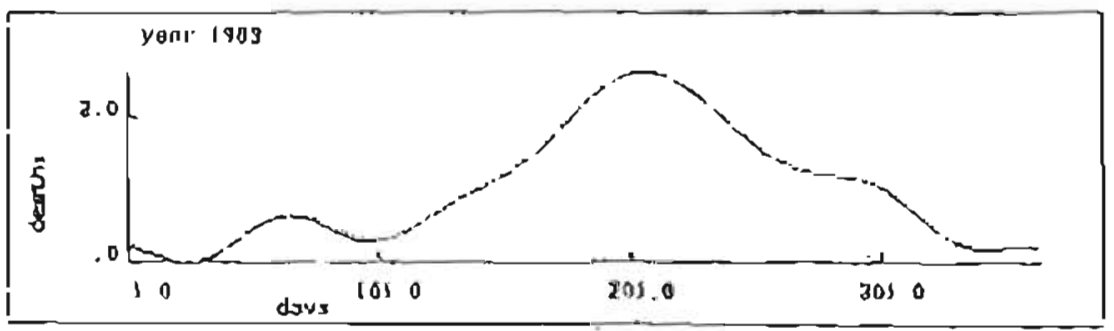

Fig.5 in example of the seasonal common pattern

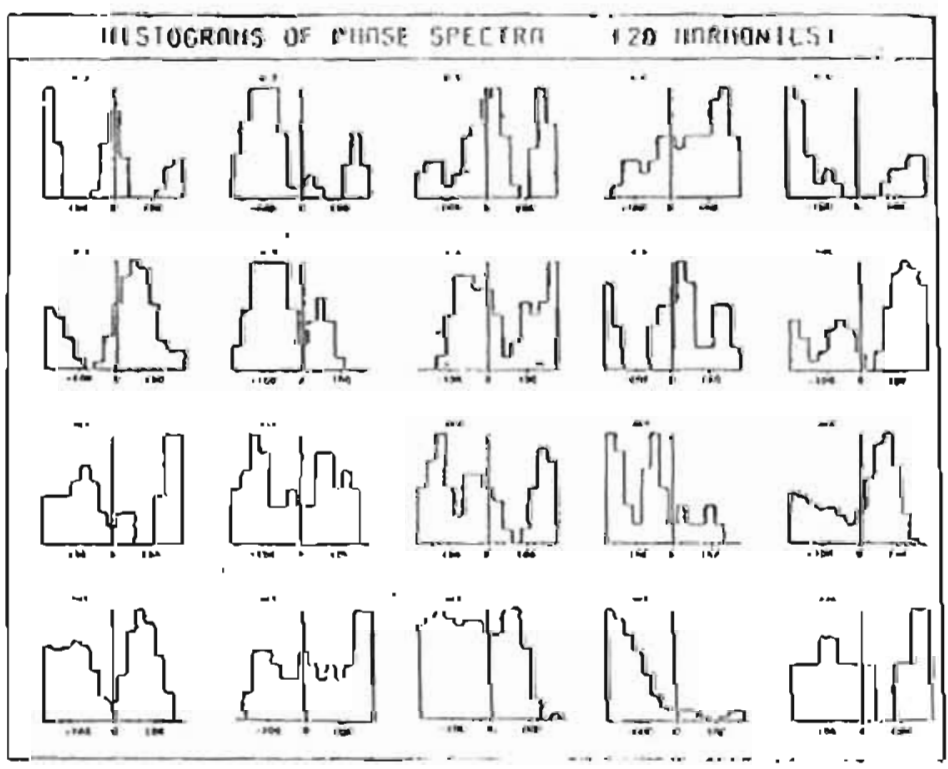
Fig. 6 Phase distributions of hacmonlcs (H." $H_{20}$ ) of neonatal
heart rate records 


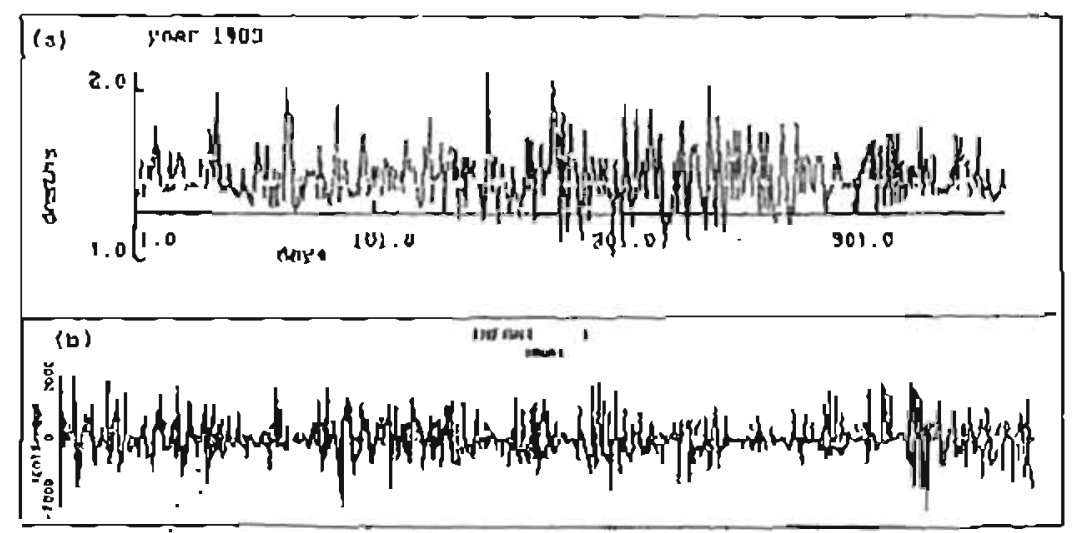

flg.7 Reslduai slgnals (hlgh-pass flitered) of:

a- Postneonatal death recoros

b- Neonatal lieaxt-rate slgnal

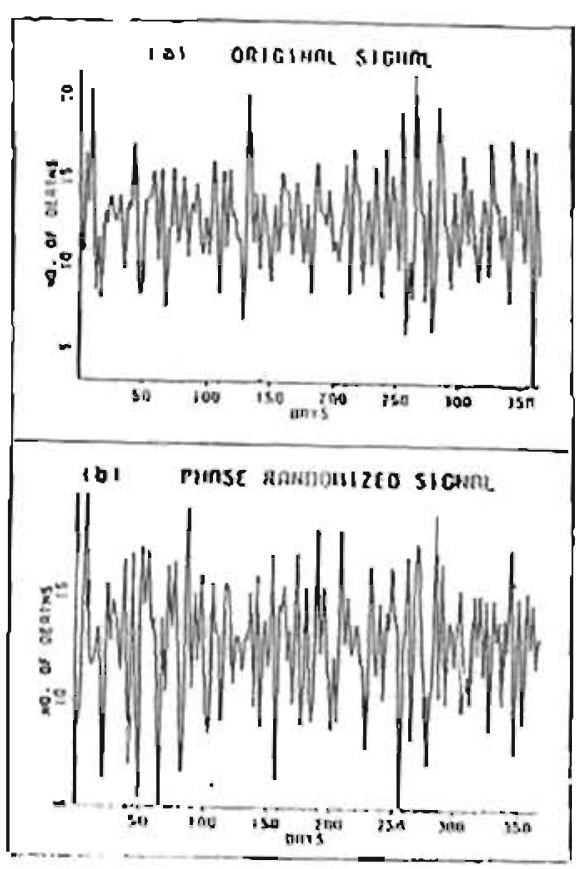

Fig.o $x$ typjcal resloual slgnal of postineonatal recoro a- original

b- Reconstructed using randomlzed phase spectrum

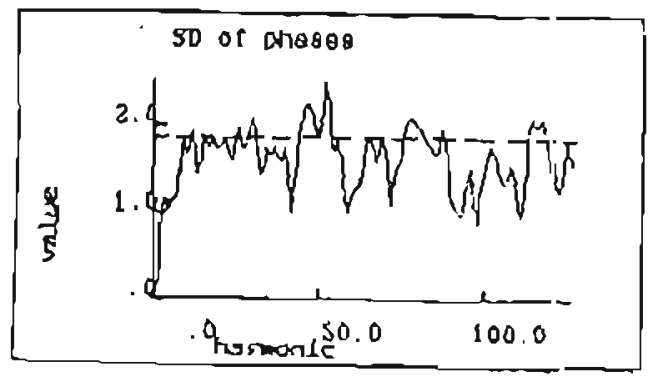

Flg. 9 Ensemble standard deviation of oliases for an ensemble of ECG beats 